\title{
Realization of genetic potential of fiber flax varieties under the influence of growth stimulators of organic origin
}

\author{
Antin Shuvar ${ }^{1}$, Natalia Rudavska ${ }^{1}$, Ivan Shuvar ${ }^{2}$, and Hanna Korpita ${ }^{2, *}$ \\ ${ }^{1}$ Institute of Agriculture of the Carpathian Region NAAS, Hrushevskogo Str., Oboroshino village, \\ 81115 Pustomytivskii, Lvivska region, Ukraine \\ ${ }^{2}$ Lviv National Agrarian University, 80381 V. Velykoho1, Dublyany, Ukraine
}

\begin{abstract}
The scientific researches on the issue of improvement of separate elements of the technology of growing medium- and late-ripening varieties of long flax in the soil-climatic conditions of the Forest-Steppe of Western Ukraine are analyzed and generalized. The relevance and expediency of foliar application of growth stimulants of organic origin (biohumate, potassium humate, rocohumin) in the recommended doses at the early stages of flax culture development at different seeding rates are highlighted. The use of the recommended elements of cultivation technology allows to realize the genetic potential of varieties of selection of the Institute of Agriculture of the Carpathian region of NAAS of Ukraine and to obtain environmentally friendly products (seeds and fiber) for different uses.
\end{abstract}

\section{Introduction}

Against the background of a significant increase in interest in the production of flax products in the world, the current state of development of its production and processing is difficult. One of the directions of rationalization of the flax industrial subcomplex is the cultivation of flax taking into account the soil-landscape, climatic and organizationaleconomic conditions of the Carpathian region. Important in increasing the yield of flax are varieties, the main requirements for which are a high level of adaptability to growing conditions, resistance of plants to adverse stress abiotic environmental factors, high quality fiber and seeds. An integrated approach to this problem is based on preserving and improving soil fertility, environmental protection, rational fertilizers and plant protection products. For the full realization of the genetic potential of fiber flax varieties it is necessary to develop optimal basic technological parameters of its cultivation (norms of seed sowing, basic and foliar feeding, application of innovative plant protection products).

Today, generally accepted technologies for growing crops do not take into account their natural adaptability, ie the adaptation of plants of agrophytocenoses to difficult growing conditions. Elements of these technologies are designed for average long-term weather conditions in the region and do not take into account their variability. Therefore, they are

\footnotetext{
* Corresponding author: korpita@ukr.net
} 
not a sufficiently effective comprehensive measure to increase the stability of agrocenoses, their protection from the adverse effects of natural factors, stable high yields and product quality. Significant climate changes, especially high air temperatures during the growing season $[1,2]$ cause risks of reduced productivity and quality of flax.

The flax industry needs new technologies that will increase the payback of energy resources and significantly increase the use of the genetic potential of varieties [3]. Flax is a dual-purpose crop. The problem of its cultivation is to achieve a balance between two opposite processes - the formation of quality seeds and solid flax fiber. The structure of crops is different, and the physiological maturity of seeds and fibers is achieved not at the same time [4].

The task of realizing the potential of flax varieties is quite complex, as the forms of cultivated plants do not have a wide ecological valence in the conditions of one or another soil-climatic zone. Therefore, the difference between the stability and yield of varieties and hybrids of flax in the areas of breeding and genetic institutions, state varietal testing and production conditions remains quite significant [5]. Adaptive technology of growing new varieties of flax plants is associated with the specific influence of environmental factors, which is determined, on the one hand, their variety, dose, duration of exposure, on the other - the biological characteristics of the culture and variety, its functional state.

At deviation of environmental conditions from optimum values at various stages of vegetation there is a self-regulation of production process both of separate plants, and all agrophytocenosis as a whole. At the same time there is a partial compensation of insufficiency of some constituent elements of size of productivity by increase in number of others. For example, the liquefaction of productive flax stalks under favorable conditions can be compensated by increased branching of plants and an increase in the number of capsules, and the insufficient number of seeds - the weight of 1000 seeds, its quality and so on. Moreover, these processes are stretched over the growing season, which enhances the adaptive capacity of plants. The results of laboratory and field tests showed that the highest dynamics of flax plant development and formation of elementary fibers occurred between the 30th and 57th day of flax growth, ie from the stage on the scale BBCH 32 to BBCH 65 . The highest fiber yield and its best quality were obtained when sowing in rows at a density of 2800 seeds $\mathrm{m}^{2}(140 \mathrm{~kg} / \mathrm{ha})$ and when harvesting flax in the green-yellow phase of maturity $(\mathrm{BBCH} 83)$. The beginning of the stage of reproductive development of flax occurs when the plants have a height of 14-16 cm (BBCH 16-17), and the highest increase in flax biomass was observed in the stage from BBCH 32 to $\mathrm{BBCH} 71$ [6].

The main factor that ensures the growth of productivity of flax varieties is the provision of nutrients to plants. Growing flax without the use of mineral fertilizers and pesticides causes its low productivity. Because flax has an underdeveloped root system, a sufficient amount of nutrients should be available in the soil. It consumes $1.30-1.51 \mathrm{~kg}$ of nitrogen, 0.37-0.57 kg of phosphorus (P205), 0.62-1.37 potassium (K2O) and 037 for the formation of 1 quintal of air-dry mass of seed and straw crop. $-0.92 \mathrm{~kg}$ of calcium $(\mathrm{CaO})$. In addition, it was found that long flax plants remove $80-90 \%$ of nitrogen, and only $10-25 \%$ of P205, from fertilizers, $4-10 \%$ - from soil, and $34.8-42.0 \%$ K20 - from fertilizers, $25.7-37.8 \%$ from the soil [7]. It is advisable to apply mineral fertilizers to the programmed crop in a certain ratio, depending on the level of soil fertility, growing area and predecessor and taking into account the coefficients of their use from the soil and fertilizers. The level of humidity and temperature determines how nutrients are absorbed from the soil and mineral fertilizers [8].

The period of maximum nutrient demand occurs at the end of phase of formation third pair of true leaves - the beginning of rapid growth. At the moment, it is possible to predict the value of the programmed harvest and partially control the process of daily growth rate and the formation of yield and product quality according to the indicators of leaf 
diagnostics [9]. During the growth stages, the need of flax plants for nutrients is relatively small, because the root system is intensively formed and the linear growth rate of stems is minimal. In this phase, flax plants use a small amount of nutrients (nitrogen - 2.4-4.3\%, phosphorus - $0.6-0.9 \%$ and potassium $-3.0-4.5 \%$ ). At the beginning of the growing season, flax plants need all the nutrients in an accessible form at a certain ratio. Lack of them inhibits growth and development, which leads to lower yields.

One of the ways to develop the flax industry is the use of environmentally friendly and economically sound technologies for growing flax, which minimize chemical plant protection products and intensify their growth and development and the use of fertilizers and biological protection [10,11].

In recent years, the Institute of Agriculture of the Carpathian Region of NAAS has conducted systematic research to study the biological characteristics of oilseed and fiber flax varieties suitable for cultivation in the region by organic technology, finding ways to optimize elements of cultivation technology, including the use of organic products and micronutrients., which are a source of environmentally friendly nutrition, capable of nitrogen fixation and phosphorus mobilization of plants and will be able to provide stable yields with high product quality $[12,13]$.

With the strengthening of the tendency of greening the cultivation of agricultural crops, agrotechnical methods with the use of plant growth regulators are intensively introduced $[14,15]$. Studies of the vast majority of research institutions have shown a significant impact of plant growth regulators in improving productivity and crop protection. It is established that the latest domestic regulators of production growth are at the level of the best world developments in terms of efficiency, and significantly outweigh the cost $[16,17]$.

Therefore, humanity is increasingly focusing on the biologization of agriculture and the use of organic technologies for growing crops in general and flax in particular. The use of these principles and mechanisms allows to obtain environmentally friendly products for medical, nutrition (children's, dietary, etc.), cosmetic purposes. Particularly relevant is the transition to biologized technologies for growing flax in conditions of sufficient and excessive moisture in the western forest-steppe, which determine the method and parameters of tillage, sowing dates, seeding rates, fertilization time and dose, etc.

The purpose of research is to establish the peculiarities of the formation of yield and quality of fiber flax varieties of different maturity groups depending on the application:

- foliar fertilization with growth stimulants of organic origin in combination with complex microfertilizers;

- mineral nutrition, and on their basis to improve the technology of growing crops in commercial crops;

- seeding rates for varieties of different maturity groups.

\section{Material and methods}

The research was carried out in a five-field crop rotation of the crop department of the Institute of Agriculture of the Carpathian region of NAAS of Ukraine during 2016-2018 on gray forest surface gleyed soil, arable layer $(0-20 \mathrm{~cm})$ which was characterized by the following agrochemical parameters: humus (according to Tyurin) - 1, 6-1.7\%, pH (salt) 5.9-6.0 (weakly acidic with approach to neutral). The relief of the experimental plots is mainly flat, alkaline-hydrolyzed nitrogen (according to Cornfield) - 96-105 mg / kg of soil, mobile phosphorus (according to Kirsanov) - 111-116, exchangeable potassium (according to Kirsanov) - 102-107 mg / $\mathrm{kg}$ of soil. According to the current gradation, such soil has a low supply of nitrogen, medium - phosphorus and low - potassium. Scheme of the experiment: Factor A. Varieties of flax: 1. Glinum (control); 2. Miander; 3. Oberih; factor B. Sowing rate: 1.19 mln.germ. seeds / ha (control); $2.22 \mathrm{mln}$.germ. seeds / ha; 3.25 
mln.germ. seeds / ha; Factor C. Fertilizer background: 1. N30P60K90 (control); 2. N30P60K90 + potassium humate (2 1/ ha); 3. N30P60K90 + biohumate (2 1/ ha); 4. $\mathrm{N} 30 \mathrm{P} 60 \mathrm{~K} 90$ + rocohumin $(3 \mathrm{l} / \mathrm{ha})$. The experiment was repeated four times. The total area of the experimental plot is $36 \mathrm{~m}^{2}$, the accounting area is $25 \mathrm{~m}^{2}$. Agrotechnics is generally accepted for the Western Forest-Steppe zone. Predecessor - grain crops. Tillage consisted of the following measures: stubble peeling, furrow plowing to a depth of $20-22 \mathrm{~cm}$, double spring cultivation, the first to $8-10 \mathrm{~cm}$, and the second to the depth of seed wrapping with harrowing and rolling with ring-spur rollers. Sowing was carried out at the optimal early stage, with the possibility of entering the field.

The research was carried out according to the generally accepted method [18]. Brief description of the studied drugs: potassium humate "Humate-leaf" is a liquid complex concentrated preparation, which contains a humic complex, further enriched with trace microelements in chelated form and amino acids. Due to the chelated structure of the preparation is rapidly absorbed by plants compared to inorganic analogues. Humic substances that are part of the drug have a pronounced effect of growth stimulant. The composition of the drug: Humic acids - 79\%, fulvic acids - 7\%, succinic acid - 25-26 g / 1 , potassium (K2O) 15-17 g / 1, surfactant adjuvant - 50-52 g / 1, amino acids - 50-55 g/ 1 . Biohumate (potassium salts of humic acids) is a liquid concentrated humic preparation made on the basis of lowland peat. Is a growth stimulant to increase growth, reduce fallout, increase the resistance of plants to stress factors of the growing season in dry, wet and cold years, to high doses of mineral fertilizers. Rocohumin is a liquid concentrated humic preparation made on the basis of poultry industry waste. The third part of rocohumin is a protein base of liquefied chicken feathers. These are 17 amino acids and fragments of proteins - peptides and polypeptides, including keratin. This protein mass contains bound nitrogen, phosphorus and potassium, humates and a complex of trace elements in chelated form. Among the trace elements - $\mathrm{Cu}, \mathrm{Zn}, \mathrm{Fe}, \mathrm{S}, \mathrm{Mn}$, B. Preparations for foliar feeding were introduced into the phase of formation third pair of true leaves according to the experimental scheme.

Weather conditions during the years of research differed in fluctuations in hydrothermal parameters, which affected the growth and development of plants, the formation of elements of productivity and yield and grain quality of flax. Analysis of the state of crops and meteorological conditions shows that in our region in recent years there has been a trend of sharp temperature changes, significant warming in some periods and extremely uneven humidity, which causes physiological stress in plants during the growing season, which has some negative impact during and seed and fiber maturation. The different course of meteorological conditions in the years of research allowed to establish the effectiveness of the use of growth stimulants of organic origin.

\section{Results and discussion}

The use of foliar different complex preparations with growth stimulating effect and complex of microelements (potassium humate, biohumate, rocohumin) in general caused a slight (1-3 days) increase in the duration of the growing season of flax plants, which accordingly had some effect on productivity. Regarding the manifestation of varietal characteristics, the duration of the growing season in 2018 on the background of mineral nutrition N30P60K90 was for the variety Glinum - 94 days, and for varieties Miandr and Oberih - 97 days, which is 14 days longer than the previous year.

The sowing rates of the studied varieties of fiber flax had a certain effect on the field germination of seeds. Analyzing such indicators as field germination and number of plants per $1 \mathrm{~m}^{2}$ (full seedlings), it can be noted that they were higher when using lower seeding rates for all studied varieties. In particular, for the Glinum variety, the increase in sowing 
rate from 19 to $25 \mathrm{mln}$.germ. seeds / ha decreased the field germination rate from $80.6 \%$ to $78.8 \%$ on average over 3 years (1.8\%). For Miander and Oberih varieties the trend was similar and the field germination rate ranged from $78.8-81.0 \%$ and $77.5-80.1 \%$, respectively.

An important condition for the optimal provision of plants with nutrients, growth and development, the use of plants of their potential is the correct choice of seeding rate. The amount of moisture, carbon dioxide and light that they will be provided with during the growing season depends on the density of the plants. In thickened crops, plants form insufficiently filled seeds, which leads to reduced productivity. On liquefied crops, yields are reduced due to underutilization of the nutrient area, the formation of unproductive branches and increased weediness of crops. For the studied varieties there was a decrease in plant survival with increasing sowing rate from 19.0 to $22.0 \mathrm{mln}$.germ. seeds / ha by 1.8 $2.6 \%$.

The use of foliar different preparations with the content of growth stimulants and a complex of microelements led to a certain decrease in the number of plants that died during the growing season in the range of $0.6-4.3 \%$ (0.07-0.57 million units / ha). The use of potassium humate $(21 /$ ha) reduced the percentage of plants that died by $1.0-2.7 \%$, biohumate (2.0 1/ ha) - 0.5-4.0\% and rocohumin / ha) - 1.7-4.3\%.

During the research, the Oberih variety was characterized by higher plant survival during the growing season at all seeding rates compared to the Glinum and Miander varieties.

The sowing rate also had some influence on the development and spread of anthracnose (Colletotrichum lini L.) for the studied varieties. In particular, increasing the seeding rate from 19 to 25 million inhabitants / ha increased the degree of anthracnose by $1-3 \%$ (1.0$4.0 \%$ ), and the spread of the disease increased by $4.0-8.0 \%$ ( $4.0-16.0 \%)$. The lowest rates of disease development were observed in the variety Glinum - 1.0-3.0\%, and in the onset of early yellow ripeness - in the variety Oberih (2.0-4.0\%).

The level of yield of flax straw and seeds of varieties of different ecological type changed under the influence of seeding rates and fertilizer backgrounds (Table 1).

Table 1. Productivity of flax depending on elements of technology of cultivation in commodity crops (average for 2016-2018), t/ha

\begin{tabular}{|c|c|c|c|c|c|c|c|}
\hline \multirow[b]{2}{*}{ № } & \multirow{2}{*}{$\begin{array}{l}\text { Seed } \\
\text { sowing } \\
\text { rate } \\
\text { million } \\
\text { psc./ha }\end{array}$} & \multirow[b]{2}{*}{ Fertilizers $(\mathrm{C})$} & \multicolumn{2}{|c|}{ Flax straw } & \multicolumn{3}{|c|}{ Seeds } \\
\hline & & & $\begin{array}{l}\text { Average } \\
\text { for } 3 \text { years }\end{array}$ & $\begin{array}{l} \pm \text { to } C \\
\text { t/ha }\end{array}$ & \begin{tabular}{|c|} 
Average \\
for 3 years
\end{tabular} & $\begin{array}{l} \pm \text { to } C, \\
\text { t/ha }\end{array}$ & $\begin{array}{l} \pm \text { to } \mathrm{C} \\
\quad \%\end{array}$ \\
\hline \multicolumn{8}{|c|}{ (A) Glinum variety (C) } \\
\hline 1 & \multirow{4}{*}{$\begin{array}{l}19,0(\mathrm{C}) \\
\text { (B) }\end{array}$} & N30P60K90 (control) (C) & 5,97 & - & 0,89 & - & - \\
\hline 2 & & $\begin{array}{l}\text { N30P60K } 90+\text { potassium } \\
\text { humate }\end{array}$ & 6,42 & 0,45 & 0,98 & 0,02 & 2,51 \\
\hline 3 & & N30P60K90 + biohumate & 6,31 & 0,34 & 0,91 & 0,03 & 3,85 \\
\hline 4 & & $\mathrm{~N} 30 \mathrm{P} 60 \mathrm{~K} 90+$ rocohumin & 6,39 & 0,42 & 0,90 & 0,03 & 3,38 \\
\hline 5 & \multirow{4}{*}{22,0} & N30P60K90 (control) (C) & 6,63 & 0,66 & 0,75 & $-0,04$ & $-4,49$ \\
\hline 6 & & $\begin{array}{l}\text { N30P60K90+ potassium } \\
\text { humate }\end{array}$ & 7,02 & 1,05 & 0,82 & $-0,02$ & $-2,34$ \\
\hline 7 & & N30P60K90 + biohumate & 6,97 & 1,00 & 0,76 & $-0,01$ & $-1,08$ \\
\hline 8 & & $\mathrm{~N} 30 \mathrm{P} 60 \mathrm{~K} 90+$ rocohumin & 7,06 & 1,09 & 0,73 & $-0,01$ & $-1,60$ \\
\hline 9 & \multirow{2}{*}{25,0} & N30P60K90 (control) (C) & 7,06 & 1,09 & 0,65 & $-0,21$ & $\begin{array}{c}- \\
23,82 \\
\end{array}$ \\
\hline 10 & & $\mathrm{~N} 30 \mathrm{P} 60 \mathrm{~K} 90+$ potassium & 7,56 & 1,59 & 0,69 & $-0,20$ & - \\
\hline
\end{tabular}




\begin{tabular}{|c|c|c|c|c|c|c|c|}
\hline & & humate & & & & & 22,34 \\
\hline 11 & & N30P60K90 + biohumate & 7,31 & 1,34 & 0,69 & $-0,19$ & 21,35 \\
\hline 12 & & N30P60K90 + rocohumin & 7,40 & 1,43 & 0,64 & $-0,19$ & $\begin{array}{c}- \\
21,74 \\
\end{array}$ \\
\hline \multicolumn{8}{|c|}{ Miander variety } \\
\hline 13 & \multirow{4}{*}{$19,0(\mathrm{C})$} & N30P60K90 (control) (C) & 6,04 & - & 1,09 & - & - \\
\hline 14 & & $\begin{array}{l}\text { N30P60K90+ potassium } \\
\text { humate }\end{array}$ & 6,42 & 0,38 & 1,14 & 0,09 & 8,44 \\
\hline 15 & & N30P60K90 + biohumate & 6,28 & 0,24 & 1,17 & 0,11 & 10,23 \\
\hline 16 & & N30P60K90 + rocohumin & 6,29 & 0,25 & 1,18 & 0,10 & 9,60 \\
\hline 17 & \multirow{4}{*}{22,0} & N30P60K90 (control) (C) & 6,85 & 0,81 & 0,98 & $-0,14$ & $\begin{array}{c}- \\
13,03 \\
\end{array}$ \\
\hline 18 & & $\begin{array}{l}\text { N30P60K90+ potassium } \\
\text { humate }\end{array}$ & 7,25 & 1,21 & 1,01 & $-0,12$ & $\begin{array}{c}- \\
10,77 \\
\end{array}$ \\
\hline 19 & & N30P60K90 + biohumate & 7,01 & 0,97 & 1,03 & $-0,10$ & $-9,29$ \\
\hline 20 & & N30P60K90 + rocohumin & 6,99 & 0,95 & 1,04 & $-0,11$ & $-9,81$ \\
\hline 21 & \multirow{4}{*}{25,0} & N30P60K90 (control) (C) & 7,46 & 1,42 & 0,85 & $-0,34$ & $\begin{array}{c}- \\
31,01\end{array}$ \\
\hline 22 & & $\begin{array}{l}\mathrm{N} 30 \mathrm{P} 60 \mathrm{~K} 90+\text { potassium } \\
\text { humate }\end{array}$ & 7,96 & 1,92 & 0,87 & $-0,32$ & - \\
\hline 23 & & N30P60K90 + biohumate & 7,84 & 1,80 & 0,89 & $-0,31$ & $\begin{array}{c}- \\
28,04 \\
\end{array}$ \\
\hline 24 & & N30P60K90 + rocohumin & 7,89 & 1,85 & 0,89 & $-0,31$ & $\begin{array}{c}- \\
28,46\end{array}$ \\
\hline \multicolumn{8}{|c|}{ Oberih variety } \\
\hline 25 & \multirow{4}{*}{$19,0(\mathrm{C})$} & N30P60K90 (control) (C) & 6,33 & 0,00 & 0,95 & - & - \\
\hline 26 & & $\begin{array}{l}\mathrm{N} 30 \mathrm{P} 60 \mathrm{~K} 90+\text { potassium } \\
\text { humate }\end{array}$ & 6,72 & 0,39 & 0,95 & 0,03 & 2,68 \\
\hline 27 & & N30P60K90 + biohumate & 6,67 & 0,34 & 0,94 & 0,04 & 4,15 \\
\hline 28 & & N30P60K90 + rocohumin & 6,52 & 0,19 & 0,98 & 0,03 & 3,63 \\
\hline 29 & \multirow{4}{*}{22,0} & N30P60K90 (control) (C) & 7,33 & 1,00 & 0,77 & $-0,12$ & $\begin{array}{c}- \\
12,21 \\
\end{array}$ \\
\hline 30 & & $\begin{array}{l}\text { N30P60K90+ potassium } \\
\text { humate }\end{array}$ & 7,71 & 1,38 & 0,81 & $-0,10$ & $\begin{array}{c}- \\
10,28 \\
\end{array}$ \\
\hline 31 & & N30P60K90 + biohumate & 7,56 & 1,23 & 0,82 & $-0,09$ & $-9,02$ \\
\hline 32 & & $\mathrm{~N} 30 \mathrm{P} 60 \mathrm{~K} 90+$ rocohumin & 7,51 & 1,18 & 0,84 & $-0,09$ & $-9,47$ \\
\hline 33 & \multirow{4}{*}{25,0} & N30P60K90 (control) (C) & 7,93 & 1,60 & 0,62 & $-0,21$ & $\begin{array}{c}- \\
21,89\end{array}$ \\
\hline 34 & & $\begin{array}{l}\text { N30P60K90+ potassium } \\
\text { humate }\end{array}$ & 8,30 & 1,97 & 0,65 & $-0,19$ & 20,22 \\
\hline 35 & & N30P60K90 + biohumate & 8,12 & 1,79 & 0,65 & $-0,18$ & $\begin{array}{r}- \\
19,12 \\
\end{array}$ \\
\hline 36 & & $\mathrm{~N} 30 \mathrm{P} 60 \mathrm{~K} 90+$ rocohumin & 8,23 & 1,90 & 0,64 & $-0,19$ & $\overline{-}$ \\
\hline
\end{tabular}

$\mathrm{LSD}_{0,5}$

A $0,22-0,370,23-0,31$

B $0,33-0,450,32-0,44$

C $0.07-0,160.06-0,14$

ABC 0,010 - 0,015 0,080 - 0,012

The highest yield of flax straw on average for 3 years was obtained for the variety Oberih on the background of N30P60K90 in combination with foliar application of potassium humate fertilizer at the rate of $21 /$ ha at the phase of formation third pair of true 
leaves and using the sowing rate of $25 \mathrm{mln}$.germ. seeds./ha $-8,3 \mathrm{t} /$ ha. The increase to the variant without the use of microfertilizer was $0.7 \mathrm{t} / \mathrm{ha}(5.9 \%)$ to the control (Glinum variety $-0.74 \mathrm{t} / \mathrm{ha}$ ), where the yield of flax straw on the same variant is $7.56 \mathrm{t} / \mathrm{ha}$ ). The increase in flax straw yield from the use of rocohumin $(3 \mathrm{l} / \mathrm{ha})$ was $0.5-0.6 \mathrm{t} / \mathrm{ha}$ for the studied varieties at sowing rates of $25 \mathrm{mln}$.germ. seeds / ha.

The increase in the sowing rate from 19 to $25 \mathrm{mln}$.germ. seeds/ha led to an increase in flax straw yield by $1.09 \mathrm{t} /$ ha for the Glinum variety (5.97 and $7.06 \mathrm{t} / \mathrm{ha}$, respectively), by $1.42 \mathrm{t} /$ ha for Miander variety (from 6.04 to $7.46 \mathrm{t} / \mathrm{ha}$, respectively) and $1.6 \mathrm{t} /$ ha for the Oberih variety (from 6.33 to $7.93 \mathrm{t} / \mathrm{ha}$, respectively).

In terms of seed yield, the highest rate was obtained in the variety Miander with seeding rates of $19 \mathrm{mln}$.germ. seeds / ha and foliar application of growth stimulant rocohumin (3 1 / ha) $-1.18 \mathrm{t} / \mathrm{ha}$ (increase from the drug $-0.09 \mathrm{t} / \mathrm{ha}$ ). Seed yield for this variety on the background of N30P60K90 exceeded that of Glinum by $0.20 \mathrm{t} / \mathrm{ha}$, and for Oberih - by $0.14 \mathrm{t} / \mathrm{ha}$. The results of laboratory analyzes showed that the content of heavy metals in flax seeds in all variants of the experiment was significantly lower than the MPC. In particular, the content of $\mathrm{Zn}$ was $15.9-17.3 \mathrm{mg} / \mathrm{kg}$ (MPC - $50 \mathrm{mg} / \mathrm{kg}$ ), $\mathrm{Pb}-0.01-0.08$ (MPC - $0.3 \mathrm{mg} / \mathrm{kg}$ ), Cd - not more than 0.012 (MPC - $0.03 \mathrm{mg} / \mathrm{kg}$ ), Cu - 7.2-8.1 mg / kg (MPC $-10.0 \mathrm{mg} / \mathrm{kg}$ ), which indicates the environmental safety of the products.

Regarding the effectiveness of growth-promoting drugs in varieties of different maturity groups, their effect differed. The use of potassium humate and rocohumin on the Glinum variety had a greater effect on the yield of flax straw (5.6-5.9\%), and for the varieties Miander and Oberih its using had a greater effect on the increase in seed yield (6.1-9.6\%).

These productivity indicators were formed due to the change of the corresponding indicators of the crop structure (Table 2). The use of micronutrients has increased the overall and technical height of the stem and the number of capsules on the plant. The highest increase in total and technical height for the variety Oberih was obtained at the seeding rates of 19 and $22 \mathrm{mln}$.germ. seeds / ha 2.9 and $2.1 \mathrm{~cm}$, respectively. The increase in the sowing rate of seeds to $25 \mathrm{mln}$.germ. seeds / ha caused a decrease in the total height to $87.8 \mathrm{~cm}$. For varieties Glinum and Miander, this figure was in the range of $84.3-90.6 \mathrm{~cm}$. technical height of plants at the same seeding rates $-83.3-84.6 \mathrm{~cm}$, which exceeds the same figure for varieties Miander and Glinum by $8.1-9.4 \mathrm{~cm}$.

Table 2. Indicators of yield structure of fiber flax varieties varieties depending on seeding rates.

\begin{tabular}{|c|c|c|c|c|c|c|c|c|}
\hline Variety & $\begin{array}{c}\text { Seed sowing } \\
\text { rate } \\
\text { mln. psc./ha }\end{array}$ & $\begin{array}{c}\text { Total } \\
\text { height, } \\
\text { sm }\end{array}$ & $\begin{array}{c} \pm \text { to C, } \\
\text { sm }\end{array}$ & $\begin{array}{c}\text { Technical } \\
\text { height, sm }\end{array}$ & $\begin{array}{c} \pm \text { to C, } \\
\text { sm }\end{array}$ & $\begin{array}{c}\text { Number of } \\
\text { capsules on } \\
\text { the plant, pcs }\end{array}$ & $\begin{array}{c} \pm \text { to C, } \\
\text { psc. }\end{array}$ & $\begin{array}{c}\text { Diameter of the } \\
\text { middle part of } \\
\text { the stem, mm }\end{array}$ \\
\hline \multirow{3}{*}{ Glinum } & 19 & 90,6 & - & 78,7 & - & 5,6 & - & 1,5 \\
\cline { 2 - 9 } & 22 & 88,4 & $-2,2$ & 79,7 & 0,8 & 4,6 & $-1,1$ & 1,4 \\
\cline { 2 - 9 } & 25 & 84,3 & $-6,3$ & 80,4 & 1,5 & 4,3 & $-1,3$ & 1,6 \\
\hline \multirow{3}{*}{ Miander } & 19 & 89,0 & $-1,6$ & 75,2 & $-3,7$ & 8,0 & 2,4 & 1,7 \\
\cline { 2 - 9 } & 22 & 87,6 & $-3,0$ & 76,5 & $-2,4$ & 5,8 & 0,2 & 1,7 \\
\hline \multirow{3}{*}{ Oberih } & 25 & 84,6 & $-6,1$ & 77,5 & $-1,5$ & 4,5 & $-1,1$ & 1,5 \\
\cline { 2 - 9 } & 19 & 93,5 & 2,9 & 84,6 & 5,6 & 4,9 & $-0,7$ & 1,5 \\
\cline { 2 - 9 } & 22 & 92,7 & 2,1 & 83,3 & 4,4 & 4,8 & $-0,8$ & 1,5 \\
\hline
\end{tabular}

*Fertilizer background $-\mathrm{N}_{30} \mathrm{P}_{60} \mathrm{~K}_{90}$

Regarding the number of capsules on average per plant, the highest rates were obtained when sowing the variety Miander at sowing rates of $19 \mathrm{mln}$.germ. seeds / ha -8.0 pieces, which is 2.1-2.4 pieces / plant higher than the same figure for varieties Glinum and Oberih (4.9-5.6 pcs. / plant). The application of potassium humate biofertilizer led to an increase in the number of capsules on the plant by $0.8 \mathrm{pcs} /$ plant, and the introduction of biohumate and rocohumine - by 0.3-0.4 pcs. / plant. 
For Glinum, Oberih and Miander varieties, the application of microfertilizers foliarly contributed to the increase of the given indicators of yield structure by $5.8-7.4 \%$. If the indicators of general and technical height were higher with the use of potassium humate, the use of rocohumine and biohumate contributed to the formation of more capsules on the plant.

The studied agrotechnical factors also had a certain influence on the indicators of fiber quality (Table 3). The highest content of total fiber in the trust for an average of 2 years (2016-2017) was observed in the variety Glinum on the background of nutrition N30P60K90 - 32.7\%, which is $6.0 \%$ higher compared to the variety Miander and $3.1 \%$ compared to variety Oberih. The increase in seed sowing rate from 19 to $25 \mathrm{mln}$.germ. seeds / ha had a tendency to reduce the fiber content in the trust this year, and the use of the studied microfertilizers showed a certain tendency to increase its content in plants for all studied varieties.

Table 3. Indicators of productivity and quality of flax fiber with. Glinum depending on agrotechnical factors, the average for 2016-2017.

\begin{tabular}{|c|c|c|c|c|c|c|}
\hline $\begin{array}{c}\text { № } \\
\text { п/п }\end{array}$ & $\begin{array}{l}\text { Seed sowing } \\
\text { rate } \\
\text { mln. psc./ha } \\
\text { (A) }\end{array}$ & $\begin{array}{l}\text { Fertilizer background } \\
\text { (B) }\end{array}$ & $\begin{array}{l}\text { The fiber content } \\
\text { in the trust, } \%\end{array}$ & $\underset{\mathrm{t}}{\text { Fiber yield, }}$ & $\begin{array}{c} \pm \text { to } \mathrm{C} \\
\mathrm{t}\end{array}$ & $\begin{array}{c} \pm \text { to } \mathrm{C}, \\
\%\end{array}$ \\
\hline 1 & \multirow{4}{*}{$19,0(\mathrm{C})$} & N30P60K90 (control) (C) & 29,7 & 1,71 & - & - \\
\hline 2 & & $\begin{array}{l}\text { N30P60K90 + potassium } \\
\text { humate }\end{array}$ & 30,5 & 1,88 & 0,17 & 9,8 \\
\hline 3 & & N30P60K90 + biohumate & 29,6 & 1,86 & 0,15 & 8,7 \\
\hline 4 & & $\mathrm{~N} 30 \mathrm{P} 60 \mathrm{~K} 90+$ rocohumin & 29,9 & 1,87 & 0,16 & 9,5 \\
\hline 5 & \multirow{4}{*}{22,0} & N30P60K90 (control) (C) & 30,9 & 2,02 & 0,31 & 18,3 \\
\hline 6 & & $\begin{array}{l}\text { N30P60K90+ potassium } \\
\text { humate }\end{array}$ & 31,8 & 2,13 & 0,42 & 24,5 \\
\hline 7 & & N30P60K90 + biohumate & 32,2 & 2,12 & 0,41 & 24,0 \\
\hline 8 & & N30P60K90 + rocohumin & 31,7 & 2,18 & 0,47 & 27,6 \\
\hline 9 & \multirow{4}{*}{25,0} & N30P60K90 (control) (C) & 33,1 & 2,06 & 0,35 & 20,6 \\
\hline 10 & & $\begin{array}{l}\text { N30P60K90+ potassium } \\
\text { humate }\end{array}$ & 33,0 & 2,28 & 0,57 & 33,4 \\
\hline 11 & & N30P60K90 + biohumate & 32,7 & 2,21 & 0,50 & 29,3 \\
\hline 12 & & N30P60K90+ rocohumin & 32,5 & 2,25 & 0,54 & 31,6 \\
\hline
\end{tabular}

$\mathrm{LSD}_{0,5}$

A $2,140,21$

B 2,08 0.63

AB $0,320,037$

However, the studied agronomic factors had a significant impact on the productivity of all fiber. The highest indicator on average for 2016-2017 was obtained in the variety Oberih $-2.34 \mathrm{t} /$ ha at the sowing rate of $25 \mathrm{mln}$.germ. seeds / ha on the background of N30P60K90 in combination with foliar application of microfertilizer potassium humate at the rate of $21 /$ ha. In a similar variant, $2.28 \mathrm{t} /$ ha was obtained in the Glinum variety and $1.83 \mathrm{t} /$ ha for the Miander variety, which is $0.06 \mathrm{t} /$ ha lower than in the Oberih variety.

The studied microfertilizers differently affected the productivity of all fiber in flax varieties. The use of potassium humate $(2.01 / \mathrm{ha})$ on average for 2 years on the variety Glinum at different seeding rates caused an increase in fiber yield in the range of 0.11-0.17 $\mathrm{t} / \mathrm{ha}$. For biohumate and rocohumin the increase was slightly lower and was in the range of $0.08-0.15 \mathrm{t} / \mathrm{ha}$. For the varieties Miandr and Oberih the trend was similar and the most effective was the use of potassium humate at a rate of $2.01 /$ ha at sowing rates of 25 $\mathrm{mln}$.germ. seeds/ha - an increase to the variant of background fertilizer was $0.12-0.17 \mathrm{t} / \mathrm{ha}$.

Regarding the qualitative properties of the fiber, the highest strength parameters were observed for the variety Glinum (35.5-42.0 daN), for the varieties Miander and Oberih it 
was slightly lower and amounted to 37.3-39.7 daN. The use of growth stimulator rocohumin on the variety Glinum led to an increase in this indicator by $2.5-5.5 \mathrm{daN}$ depending on the seeding rate.

\section{Conclusions}

Therefore, to obtain a stable productivity of flax (fiber 1.86-2.36 t / ha, seeds $0.95-1.18 \mathrm{t}$ / ha) in the soil and climatic conditions of the Western Forest-Steppe, environmentally friendly products, it is advisable to grow varieties of Oberih, Miander, Glinum, on the background of mineral nutrition N30P60K90 and apply growth stimulants of organic origin potassium humate $(2.01 / \mathrm{ha})$, biohumate $(2.0 \mathrm{l} / \mathrm{ha})$ or rocohumin $(3.0 \mathrm{l} / \mathrm{ha})$ in the phase of formation third pair of true leaves.

The highest seed yield (1.18 t/ ha) was provided by the Miander variety under the conditions of sowing at the rate of $19 \mathrm{mln}$.germ. seeds / ha and foliar application of rocohumin (3 1/ha) (increase from growth stimulant application $-0.09 \mathrm{t} / \mathrm{ha}$ ). The content of heavy metals in the seeds did not exceed the MPC ( $\mathrm{Zn}-15.9-17.3 \mathrm{mg} / \mathrm{kg}(\mathrm{MPC}-50 \mathrm{mg} /$ $\mathrm{kg}$ ), $\mathrm{Pb}-0.01-0.08$ (MPC - $0.3 \mathrm{mg} / \mathrm{kg}$ ), $\mathrm{Cd} \leq 0.012$ (MPC - $0.03 \mathrm{mg} / \mathrm{kg}$ ), $\mathrm{Cu}-7.2-8.1 \mathrm{mg}$ $/ \mathrm{kg}$ (MPC - $10.0 \mathrm{mg} / \mathrm{kg}$ ).

The use of potassium humate, biohumate and rocohumin on the long flax variety Glinum had a greater effect on the increase in flax straw yield (5.6-5.9\%) and on the varieties Miander and Oberih - on the increase in seed yield (6.1-9.6\%). When using potassium humate, the number of capsules on the plant increased by 0.8 pieces, and with the introduction of biohumate and rocohumin - by 0.3-0.4 pieces / plant. The use of potassium humate $(2.01 / \mathrm{ha})$ on the Glinum variety at different seeding rates caused an increase in fiber yield in the range of $0.11-0.17 \mathrm{t} /$ ha, biohumate and rocohumin - in the range of $0.08-0.15 \mathrm{t} / \mathrm{ha}$.

\section{References}

1. Yu. Kornuta,. I. Hrynyk, Agroecological Journal, 2, 64 (2014)

2. A. Skorchenko, I. Karpets, V. Kovalev, Fundamentals of flax growing in modern conditions, 3 (2002)

3. S. Yagelyuk, V.Tkachuk, O. Rechun, Formation of the market of technical cultures in Ukraine, 1(11), 195 (2008)

4. I. Karpets, S. Varenyk, V. Gabenets, Bulletin of Agrarian Science, 3, 83 (2004)

5. V. Rossokha, Bulletin of Agrarian Science, 3, 66 (2009)

6. K. Heller, W. Koncewicz, M. Byczyńska, N. Lukaszewska, M. Praczyk, The Effect of Fibre Flax Growing Technologies on Ontogenesis and Cultivars Yielding Capacity, 315 (2008)

7. S. Bondarenko, Agrochemistry, 10, 74 (1974)

8. O. Lokot, I. Hrynyk, Visn. agrarian. Science, 3, 21 (2001)

9. V. Tikhomirova, O. Sorokin, N. Kuzmenko, 6, 38 (2002)

10. S. Koza, Agricultural microbiology: Interdepartmental thematic scientific collection, 12, 86 (2005)

11. V. Patika, M. Patika, Agricultural microbiology: Interdepartmental thematic scientific collection, 4, 7 (2006)

12. V. Zaluzhny, R. Voitovych, E. Bondarev, A. Shuvar, Patent for utility model 73337 IPC (2012.01) A 01 D 43/00, 18, 4 (2012) 
13. A. Shuvar, Foothill and mountain agriculture and animal husbandry, 54,120 (2012)

14. M. Klyuchevin, S. Stolyar, Agriculture and protection of plants, 2(111), 28 (2017)

15. S. Ponomarenko et al, Biostimulators of growth of plants of new generation in technologies of cultivation of agricultural crops, 63 (1997)

16. Y. Buryak, O. Chernobab, Plant growth regulators - an important element of modern technologies for growing seeds of cereals, 196 (2008)

17. M. Klyuchevich, S. Stolyar, O. Dmitrenko, Influence of plant growth regulators on sowing millet productivity in Polissya of Ukraine, 65 (2019)

18. B. Dospekhov, Methods of field experience (with the basics of statistical processing of research results), 351 (1985) 